\title{
GC-MS, LC-MS/MS, Docking and Molecular Dynamics Approaches to Identify Potential SARS-CoV-2 3-Chymotrypsin-Like Protease Inhibitors from Zingiber officinale Roscoe
}

\author{
Muhammad Sulaiman Zubair ${ }^{1, * \mathbb{D}}$, Saipul Maulana ${ }^{1}$, Agustinus Widodo ${ }^{1}$, Ramadanil Pitopang ${ }^{2}$, \\ Muhammad Arba ${ }^{3}$ and Maywan Hariono ${ }^{4, *}$ (D)
}

Citation: Zubair, M.S.; Maulana, S.; Widodo, A.; Pitopang, R.; Arba, M.; Hariono, M. GC-MS, LC-MS/MS, Docking and Molecular Dynamics Approaches to Identify Potential SARS-CoV-2 3-Chymotrypsin-Like Protease Inhibitors from Zingiber officinale Roscoe. Molecules 2021, 26, 5230. https://doi.org/10.3390/ molecules 26175230

Academic Editors: Maria Ines Dias, José Pinela and Lillian Barros

Received: 2 August 2021

Accepted: 25 August 2021

Published: 28 August 2021

Publisher's Note: MDPI stays neutral with regard to jurisdictional claims in published maps and institutional affiliations.

Copyright: (c) 2021 by the authors. Licensee MDPI, Basel, Switzerland. This article is an open access article distributed under the terms and conditions of the Creative Commons Attribution (CC BY) license (https:/ / creativecommons.org/licenses/by/ $4.0 /)$.
1 Department of Pharmacy, Faculty of Science, Tadulako University, Palu 94118, Indonesia; saifulmaulana011@gmail.com (S.M.); widodoagustinus@untad.ac.id (A.W.)

2 Department of Biology, Faculty of Science, Tadulako University, Palu 94118, Indonesia; pitopang_64@yahoo.com

3 Department of Pharmaceutical Chemistry, Faculty of Pharmacy, Halu Oleo University, Kendari 93231, Indonesia; muh.arba@uho.ac.id

4 Department of Pharmaceutical Chemistry, Faculty of Pharmacy, Sanata Darma University, Yogyakarta 55282, Indonesia

* Correspondence: sulaiman_zubair80@yahoo.co.id or sulaimanzubair@untad.ac.id (M.S.Z.); mhariono@usd.ac.id (M.H.); Tel.: +62-85242083654 (M.S.Z.); +62-89506286901 (M.H.)

Abstract: This study aims to identify and isolate the secondary metabolites of Zingiber officinale using GC-MS, preparative TLC, and LC-MS/MS methods, to evaluate the inhibitory potency on SARS-CoV-2 3 chymotrypsin-like protease enzyme, as well as to study the molecular interaction and stability by using docking and molecular dynamics simulations. GC-MS analysis suggested for the isolation of terpenoids compounds as major compounds on methanol extract of pseudostems and rhizomes. Isolation and LC-MS/MS analysis identified 5-hydro-7, 8, 2'-trimethoxyflavanone (9), (E)-hexadecyl-ferulate (1), isocyperol (2), $N$-isobutyl-(2E,4E)-octadecadienamide (3), and nootkatone (4) from the rhizome extract, as well as from the leaves extract with the absence of 9 . Three known steroid compounds, i.e., spinasterone (7), spinasterol (8), and 24-methylcholesta-7-en-3 $\beta$-on (6), were further identified from the pseudostem extract. Molecular docking showed that steroids compounds 7, 8, and 6 have lower predictive binding energies (MMGBSA) than other metabolites with binding energy of $-87.91,-78.11$, and $-68.80 \mathrm{kcal} /$ mole, respectively. Further characterization on the single isolated compound by NMR showed that 6 was identified and possessed 75\% inhibitory activity on SARS-CoV-2 3CL protease enzyme that was slightly different with the positive control GC376 (77\%). MD simulations showed the complex stability with compound 6 during 100 ns simulation time.

Keywords: Zingiber officinale; LC-MS/MS; Steroids; 24-Methylcholesta-7-en-3 $\beta$-on; 3CL Protease; SARS-CoV-2

\section{Introduction}

COVID-19, caused by the SARS-CoV-2 virus, is a global pandemic that has negatively impacted human life in this recent time. As of July 2021, approximately 196 million people have been infected, and 4.2 million have died from this disease [1]. The absence of medicine has encouraged the application of several synthetic drugs to be repurposed for combating the virus replication, such as hydroxy chloroquine and remdesivir. However, the attention for adverse side effect prompts us to find drugs that are effective and selective in inhibiting the replication of the virus $[2,3]$. To date, several targets of SARS-CoV-2 virus have been identified, such as 3 chymotrypsin-like protease, papain-like protease, RNA dependent RNA polymerase, and spike-glycoprotein, which have afforded significant 
research on discovering and developing new drugs focusing on the viral spreading inhibition. 3 Chymotrypsin-like protease (3CLpro) SARS-CoV-2 has become an interesting target, as if it is inhibited, the viral replication process will be disrupted by inhibiting the viral polyproteins cleavage [4].

Natural sources have been becoming one of options to discover such drugs since their biological diversity provides more interesting chemical skeletons and diverse structures [5,6]. The mixture of plants from Zingiberaceae family, known as medicinal herbs of "empon-empon", has been suddenly consumed by javanese in Indonesia to fight against COVID-19 during this pandemic time as they believe that this traditional herb can cure the pneumonia-like symptoms in COVID-19 patients. Zingiberaceae plants are also well and broadly distributed in several cities in Indonesia as they are commonly utilized for daily food, spicing, and medication. Zingiber officinale Roscoe (ginger) is drawing attention to be studied as this plant showed a broad pharmacological activity, such as anti-bacterial, anti-oxidant, anti-tumor, and anti-inflammatory [7-10]. Respiratory disorders, diabetes mellitus, obesity, cardiovascular, and neurodegenerative defects were also reported among diseases that can be treated using ginger [11-15]. Mostly, these activities were reported to possess the such effects due to the content of phenolic compounds, such as gingerols, shogaols, and paradols. The aqueous extract was reported to inhibit avian influenza virus $\mathrm{H}_{9} \mathrm{~N}_{2}$ activity, and its lyophilized water decoction extract was able to inhibit the proliferation of human respiratory syncytial virus in human respiratory tract cell lines $[16,17]$. The docking molecular study of its main metabolites on 3 chymotrypsin-like protease SARS-CoV-2 receptor suggested their potency as antivirus for treating COVID-19 [18].

In this present study, the isolation and identification of the bioactive compounds of Z. officinale (leaves, pseudostems and rhizomes), have been performed using combination of chromatographic/spectroscopic analysis and in silico methods. Many studies have reported this approach as successful strategy to discover potential bioactive compounds from the nature, as well as to determine their binding interaction mode on protein target [19-21]. Gas chromatography-mass spectrophotometry (GC-MS) was used to identify the major compounds for further isolation, liquid chromatography-mass spectrophotometry/mass spectrophotometry (LC-MS/MS) was used to identify the isolated compounds, and nuclear magnetic resonance (NMR) was used to elucidate the chemical structure of isolated compound. Meanwhile, molecular docking was used to predict the potential compounds that can inhibit SARS-CoV-2 3CL protease at the molecular level. To confirm the activity, an in vitro assay of the isolated compound against the SARS-CoV-2 3CL protease enzyme were also carried out to prove the insilico concept. Further molecular dynamics analysis was also performed to study the stability of the isolated compound as complex with SARS-CoV-2 3CL protease. To the best of our knowledge, this study is the first report on SARS-CoV-2 3CL protease inhibitory activity of compound from this plant.

\section{Results}

\subsection{Extraction and GC-MS Analysis of Z. officinale Methanol Extract}

The maceration extraction method has resulted the methanol extract of leaves, pseudostems, and rhizomes with the yields $1.44 \%, 8.87 \%$, and $19.81 \%$, respectively. The methanol extracts were then analyzed by GC-MS (Shimadzu, Kyoto, Japan) for the identification of chemical compounds (Supplementary Materials). It can be seen from Figure 1 that the terpenoids was found as the most abundant compounds on the pseudostems and rhizome parts with the percentage of $81.96 \%$ and $92.51 \%$, respectively. Meanwhile, in leaves, it was dominated by fatty acids with the percentage of $64.66 \%$, and terpenoid was found with only $13.47 \%$. This result suggested for the isolation of terpenoid compounds from each part of plants. Liquid-liquid extraction was then applied by using solvents with different polarity ( $n$-hexane, ethyl acetate, and water), and $n$-hexane extract was chosen for the next isolation process based on detected terpenoids compounds that are mostly a class of terpenes and sesquiterpenes. 


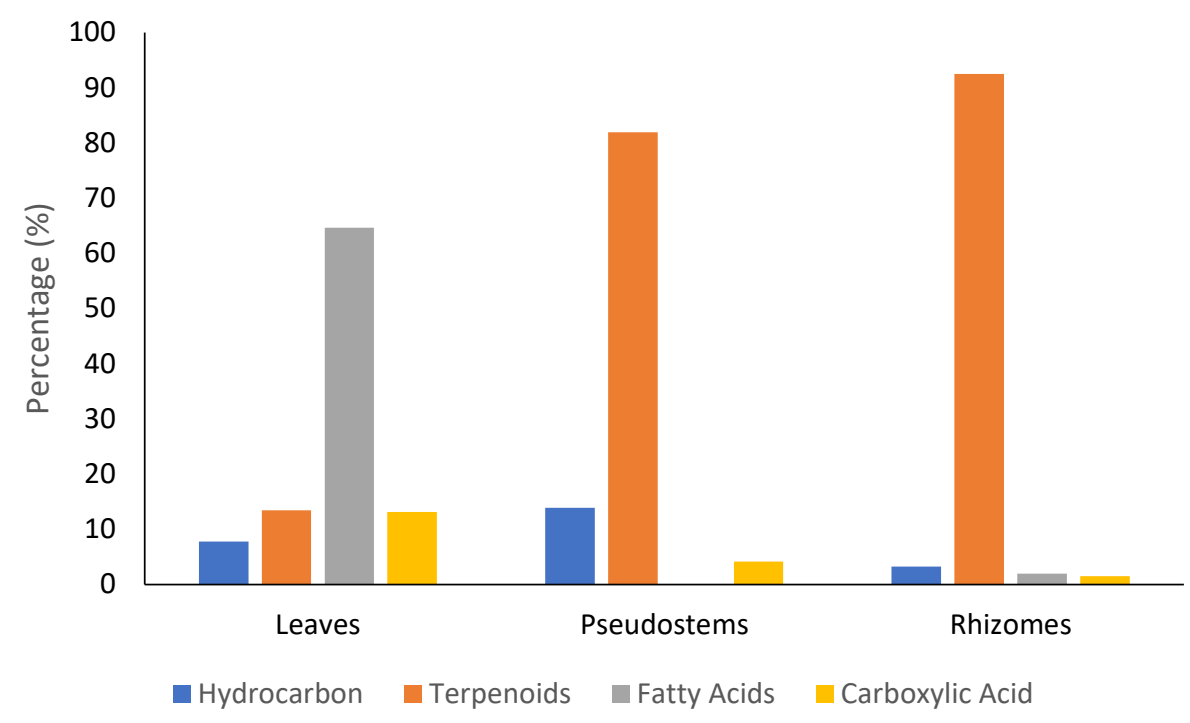

Figure 1. Diversity of secondary metabolites on Z. officinale methanol extract identified by GC-MS.

\subsection{Isolation and LC-MS/MS Identification of Isolates from Z. officinale $n$-Hexane Extract}

The $n$-hexane extracts of $Z$. officinale leaves, pseudostems and rhizomes were fractionated on a vacuum-liquid chromatography (VLC) column, with silica gel 60 and eluted by a different polarity of solvents from $n$-hexane-dichloromethane-ethyl acetate to methanol. The VLC fractions having the same profiles were combined each other to collect 21, 17, and 18 fractions from leaves, pseudostems, and rhizomes extract, respectively. Based on the identification of terpenoids compounds (assigned by the purplish color after spraying with Liebermann-Burchard reagent), the fraction number 14 (leaves), number 7 (pseudostems), and number 46 (rhizomes) were further isolated using preparative-TLC on silica gel $\mathrm{GF}_{254}$ to possess a single isolated compound from each fraction and then characterized them using LC-MS/MS (Supplementary Materials).

The LC-MS/MS successfully screened and identified several compounds that were selected based on the similarity percentage of their retardation time $\left(R_{t}\right)$ and molecular mass with the database from UNIFI 1.8 software. The isolated compounds from leaves and rhizomes showed the same compounds that are (E)-hexadecyl-ferulate (1), isocyperol (2), $N$-Isobutyl-(2E,4E)-octadecadienamide (3), and nootkatone (4) with the $\mathrm{R}_{\mathrm{t}}$ of 9.96, 9.45, 9.53 , and 9.38 minutes, respectively. A flavonoid compound, 5-hydro-7,8,2' - trimethoxyflavanone (9), was detected on rhizomes but it was absent in leaves. Meanwhile, the isolated compounds from pseudostems were identified as three known steroids, namely 24-methylcholesta-7-en-3 $\beta$-on (6), spinasterone (7), and spinasterol (8), with the $\mathrm{R}_{\mathrm{t}}$ of 10.25 , 10.29, and 10.37 minutes, respectively (Table 1$)$.

\subsection{Molecular Docking}

The LC-MS/MS identified compounds from Z. officinale $n$-hexane extracts (leaves, pseudostems, and rhizomes) were then subjected for molecular docking simulations to predict the potential compounds that can inhibit the SARS-CoV-2 3 CL protease. The optimized structures were docked to the viral protease binding site, which can be seen in Table 2. It showed that three known steroid compounds identified from the pseudostem part have lower predictive binding energies of molecular mechanics-generalized Born surface area (MMGBSA) than other compounds, including the co-crystallized ligand, and indinavir as the positive controls. Interestingly, 7,8 , and $\mathbf{6}$ exhibited binding energies with the value of $-87.41,-78.11$, and $-68.80 \mathrm{kcal} / \mathrm{mol}$, respectively, much lower than two positive controls, including baicalein $(-47.14 \mathrm{kcal} / \mathrm{mol})$ and remdesivir $(-68.55 \mathrm{kcal} / \mathrm{mol})$. Although indinavir showed binding energy slightly lower $(-76.44 \mathrm{kcal} / \mathrm{mol})$ than 6 , it is higher than $\mathbf{7}$ and $\mathbf{8}$, indicating that compounds $\mathbf{6 - 8}$ are at least comparable with the positive controls in binding to the 3CLpro. The more negative value of this energy will 
exhibit the lower free energy along with the stronger binding. Therefore, the isolated steroid compounds were suggested for further purification and NMR analysis to elucidate the molecular structure, as well as to confirm the activity on SARS-CoV-2 3CL protease enzyme.

Table 1. Compounds identified by LC-MS/MS from the isolate of Z. officinale n-hexane extract.

\begin{tabular}{|c|c|c|c|c|}
\hline$n$-Hexane Extract of & Compound's Code & Compounds Identified & $\mathbf{R}_{\mathrm{t}}(\min )$ & {$[\mathbf{M}+\mathbf{H}]^{+}$} \\
\hline \multirow{5}{*}{ Leaves } & 1 & (E)-Hexadecyl-ferulate & 9.96 & 419.3156 \\
\hline & 2 & Isocyperol & 9.45 & 221.1910 \\
\hline & 3 & $N$-Isobutyl-(2E,4E)-octadecadienamide & 9.53 & 336.3268 \\
\hline & 4 & Nootkatone & 9.38 & 219.1752 \\
\hline & 5 & Candidate mass $\mathrm{C}_{22} \mathrm{H}_{45} \mathrm{NO}$ & 10.04 & 340.3577 \\
\hline \multirow{3}{*}{ Pseudostems } & 6 & 24-methylcholesta-7-en-3 $\beta$-on & 10.25 & 399.3618 \\
\hline & 7 & Spinasterone & 10.29 & 411.3616 \\
\hline & 8 & Spinasterol & 10.37 & 413.3770 \\
\hline \multirow{5}{*}{ Rhizomes } & 1 & (E)-hexadecyl-ferulate & 9.96 & 419.3156 \\
\hline & 2 & Isocyperol & 9.45 & 221.1910 \\
\hline & 3 & $N$-Isobutyl-(2E,4E)-octadecadienamide & 9.53 & 336.3268 \\
\hline & 4 & Nootkatone & 9.38 & 219.1752 \\
\hline & 9 & 5-hydro-7,8,2'-trimethoxyflavanone & 9.25 & 329.1026 \\
\hline
\end{tabular}

Table 2. Docking molecular of identified metabolites on SARS-CoV-2 3CL protease with baicalein as the native ligand ( $\mathrm{pdb}$ code $6 \mathrm{~m} 2 \mathrm{n}$ ).

\begin{tabular}{ccc}
\hline Identified Compounds & Compound's Code & MMGBSA Binding Energy (kcal/mol) \\
\hline Spinasterone & 7 & -87.41 \\
Spinasterol & 8 & -78.11 \\
24-methylcholesta-7-en-3 $\beta$-on & $\mathbf{6}$ & -68.80 \\
N-Isobutyl-(2E,4E)- & $\mathbf{3}$ & -65.44 \\
octadecadienamide & & \\
5-hydro-7,8,2'- & $\mathbf{9}$ & -65.42 \\
trimethoxyflavanone & $\mathbf{1}$ & -65.26 \\
(E)-hexadecyl-ferulate & $\mathbf{2}$ & -62.04 \\
Isocyperol & $\mathbf{4}$ & -53.24 \\
Nootkatone & - & -47.14 \\
Baicalein & - & -76.44 \\
Indinavir & - & -68.55 \\
Remdesivir & &
\end{tabular}

SARS-CoV-2 3CL protease in complex with baicalein was chosen as the protein model based on the characteristic of this such ligand having more drug-like structure than peptidomimetic compound, which is commonly used as a protease inhibitor. Re-docking analysis of this co-crystallized nonpeptidomimetic inhibitor on the binding site of the viral protease $(\mathrm{PDB} 6 \mathrm{~m} 2 \mathrm{n})$ represents the similar pose with the reported X-ray crystallography, in which hydrogen bonding (H-bond) interaction was found between the carbonyl group of baicalein and Glu166, as well as the multiple H-bond between the two phenolic hydroxyl groups and Gly143. Hydrophobic interactions were found between the free phenyl ring of baicalein with Met49, Cys44, Pro52, and Tyr54 (Figure 2D) [22,23]. The steroid compounds showed binding modes mimicking the baicalein by polarly interacting with Glu166 and Gly143. The unique interaction was found only in the hydroxyl group of $\mathbf{8}$ through H-bond interaction with Thr190 (Figure 2B). Meanwhile, the only carboxyl group of 6 interacts via H-bond with Cys44 (Figure 2C). Definitely, there is no H-bond interaction found on 7 complexes with the 3CLpro. However, hydrophobic interaction was observed on the 
residues of Val 42, Cys 44, Leu 167, and Pro 168, giving an extra affinity to bind with the 3CLpro (Figure 2A).

A

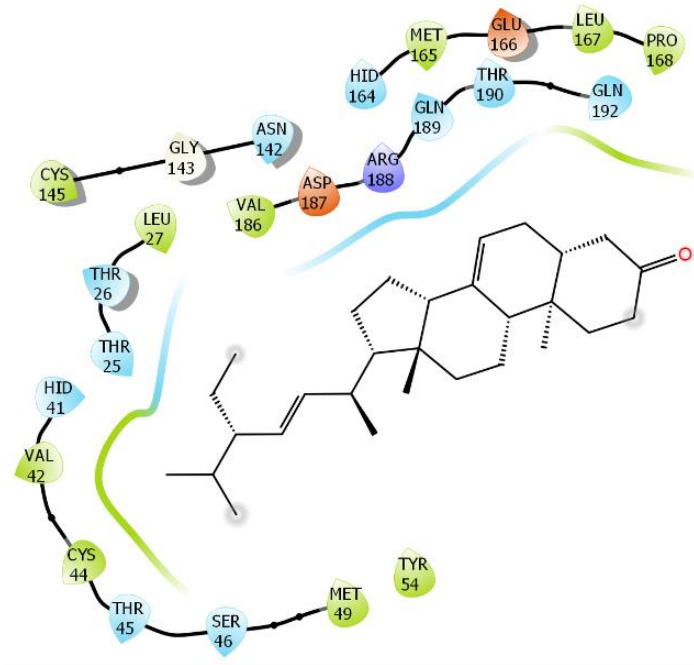

C

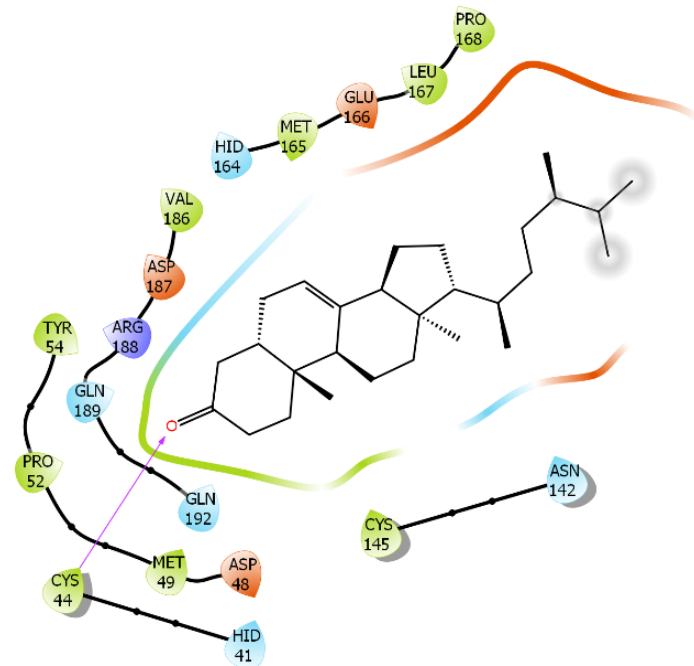

B

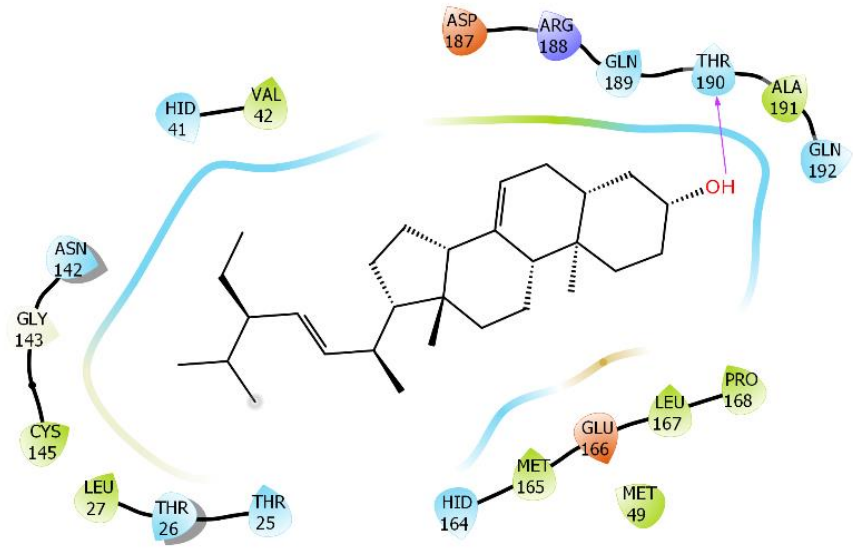

$\mathrm{D}$

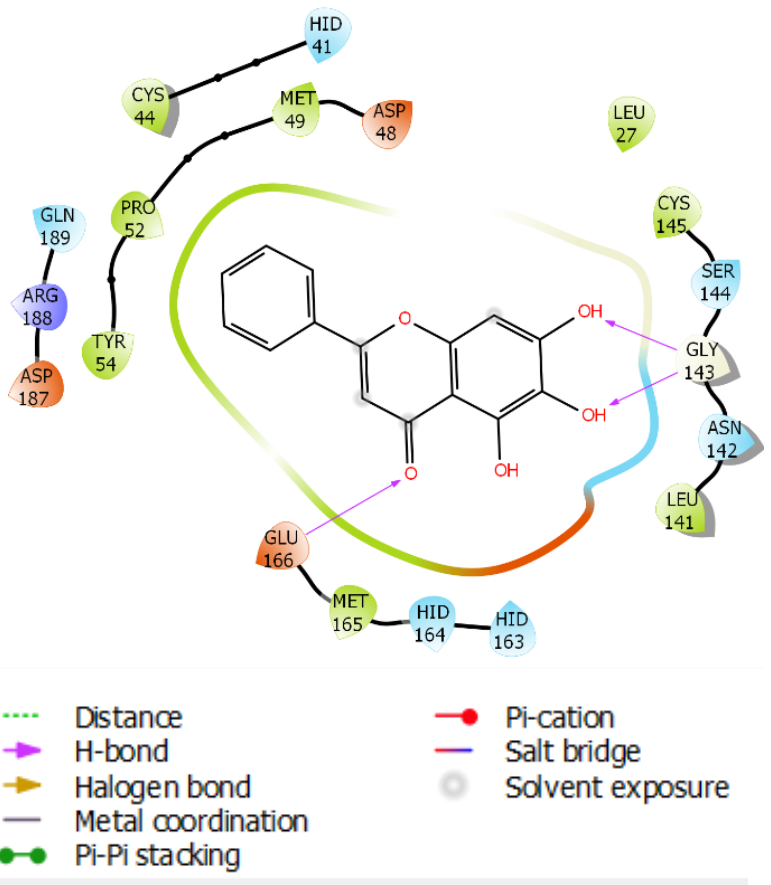

Figure 2. Molecular interactions of SARS-CoV-2 3CL protease of 7 (A), 8 (B), 6 (C) dan baicalein (D) as co-crystallized inhibitor.

\subsection{NMR Analysis and SARS-CoV-2 3CL Protease Inhibitory Activity Verification}

The steroid compounds isolated from the pseudostem part of $Z$. officinale were purified by successive TLC preparative and underwent NMR analysis that led to structure elucidation of 6 , based on ${ }^{1} \mathrm{H}$ and ${ }^{13} \mathrm{C}-\mathrm{NMR}$ spectral data that can be seen in Table 3 .

Compound $\mathbf{6}$ was isolated as a colorless powder. Its molecular mass was based on LC-MS/MS analysis with $m / z$ at $399.36180[\mathrm{M}+\mathrm{H}]^{+}$and molecular formula of $\mathrm{C}_{28} \mathrm{H}_{46} \mathrm{O}$. The ${ }^{13} \mathrm{C}$ NMR data (Table 3) supported the chemical structure with 28 carbon atom signals categorized by Distortionless Enhancement by Polarization Transfer (DEPT) experiment into six methyls, ten methylenes, eight methines, and four quaternary carbons. Six degrees of unsaturation, calculated from the molecular formula, were attributed to a carbonyl group $\left(\delta_{C} 204.6 \mathrm{ppm}\right)$ assigned for C-3, a vinylic system at C-7 and C-8 ( $\delta_{C} 140.1$ and $\left.123.7 \mathrm{ppm}\right)$, and four rings of steroidal skeleton. The ${ }^{1} \mathrm{H}$ NMR (Table 3) showed six methyl signals 
characteristic for cholesterol-type steroids skeleton, at $\delta_{\mathrm{H}}: 0.70$ and $1.17 \mathrm{ppm}$, assigned for two methyls at C-18 and C-19, and four doublet signals for a methyl at $\delta_{\mathrm{H}} 0.79,0.81,0.90$, and $1.00 \mathrm{ppm}$ for C-28, C-21, C-26, and C-27, respectively. A broad singlet at $\delta_{\mathrm{H}} 5.71$ was for olefinic proton $\mathrm{H}-7$. From the ${ }^{1} \mathrm{H}^{-1} \mathrm{H}$ COSY correlation, a spin system between $\mathrm{H}-\mathrm{C} 1$ and $\mathrm{H}-\mathrm{C} 2$ was observed and connected by long-range $\mathrm{C}-\mathrm{H}$ correlation (HMBC) between Me-19 $\left(\delta_{\mathrm{H}} 1.17, \mathrm{br} s\right)$ and C-1 (35.6), C-9 (53.8), and C-10 (38.6) established the closing of ring $\mathrm{A}$. The connection with ring $\mathrm{B}$ was supported by long-range $\mathrm{C}-\mathrm{H}$ correlation (HMBC) between $\mathrm{H}-\mathrm{C} 7\left(\delta_{\mathrm{H}} 5.71, s\right)$ and $\mathrm{C}-6$ (32.9) and $\mathrm{C}-10$ (38.6). The connection to the ring $\mathrm{C}$ was proven by the ${ }^{1} \mathrm{H}-{ }^{1} \mathrm{H}$ COSY correlation between $\mathrm{H}-\mathrm{C} 11$ and $\mathrm{H}-\mathrm{C} 12$ and supported by the long-range C-H correlation (HMBC) between Me-18 $\left(\delta_{\mathrm{H}} 0.70 \mathrm{ppm}, \mathrm{s}\right)$ and C-13 (42.2)/C-14 (39.6). The connection between steroid skeleton and its side chain was observed by HMBC long-range correlation between Me-21 $\left(\delta_{\mathrm{H}} 0.81 \mathrm{ppm}, d\right)$ and C-17 $\left(\delta_{\mathrm{C}} 48.5\right) / \mathrm{C}-22(29.1)$. Furthermore, the consecutive protons were observed from H-C-22, H-C-23, H-C-24, H-C-25, $\mathrm{H}-\mathrm{C}-26, \mathrm{H}-\mathrm{C}-27$, and H-C-28. Long-range C-H correlation (HMBC) was observed between Me-28 and C-26 (18.7), between Me-26 and C-24 (55.9), and C-25 (36.0), between Me-27 and C-23 (40.5) and C-24 (55.9) (Figure 3, Supplementary Materials).

Table 3. ${ }^{1} \mathrm{H}(500 \mathrm{MHz})$ and ${ }^{13} \mathrm{C}$ NMR $(150 \mathrm{MHz})$ spectral data of $6\left(\mathrm{CDCl}_{3}\right)$.

\begin{tabular}{|c|c|c|}
\hline P. & $\delta C(m)$ & $\delta \mathrm{H}(m)$ \\
\hline 1 & $35.6 t$ & $1.65-1.71(\mathrm{~m}) ; 1.98-2.03(\mathrm{~m})$ \\
\hline 2 & $39.5 t$ & $1.98-2.03(m)$ \\
\hline 3 & $204.6 d$ & - \\
\hline 4 & $33.9 t$ & $2.26-2.31(m, 1 \mathrm{H}) ; 2.40-2.42(m, 1 \mathrm{H})$ \\
\hline 5 & $55.8 t$ & $1.00-1.02(\mathrm{~m})$ \\
\hline 6 & $32.9 t$ & $1.27-1.28(d) ; 2.23-2.24(d)$ \\
\hline 7 & $123.7 d$ & $5.71(s, 1 \mathrm{H})$ \\
\hline 8 & $140.9 s$ & - \\
\hline 9 & $53.8 d$ & $0.95(m)$ \\
\hline 10 & $38.6 s$ & - \\
\hline 11 & $20.9 t$ & $1.00-1.01(d) ; 1.52-1.53(d)$ \\
\hline 12 & $32.0 t$ & $1.81-1.84(m)$ \\
\hline 13 & $42.2 \mathrm{~s}$ & - \\
\hline 14 & $39.6 d$ & $1.12(m)$ \\
\hline 15 & $25.4 t$ & $1.21(m)$ \\
\hline 16 & $29.7 t$ & $1.27(m)$ \\
\hline 17 & $45.8 d$ & $0.88(m)$ \\
\hline 18 & $11.9 q$ & $0.70(s, 3 \mathrm{H})$ \\
\hline 19 & $17.4 q$ & $1.17(s, 3 \mathrm{H})$ \\
\hline 20 & $31.9 d$ & $1.81-1.84(m)$ \\
\hline 21 & $19.8 q$ & $0.81-0.82(d, 3 \mathrm{H})$ \\
\hline 22 & $29.1 d$ & $1.28(\mathrm{~m})$ \\
\hline 23 & $40.5 t$ & $1.22(m, 2 \mathrm{H})$ \\
\hline 24 & $55.9 d$ & $1.07(m, 1 \mathrm{H})$ \\
\hline 25 & $36.0 d$ & $1.24(m, 1 \mathrm{H})$ \\
\hline 26 & $18.7 q$ & $0.90-0.91(d, 3 \mathrm{H})$ \\
\hline 27 & $19.5 q$ & $1.00-1.01(d, 3 \mathrm{H})$ \\
\hline 28 & $20.1 q$ & $0.79-0.82(d, 3 \mathrm{H})$ \\
\hline
\end{tabular}

Compound 6 was tested on SARS-CoV-2 enzyme inhibition and found the percentage of inhibition as $75 \%$ at the concentration of $200 \mu \mathrm{g} / \mathrm{mL}$ (Figure 4). This in vitro assay used the foster resonance energy transfer (FRET) principle, worked by measuring the fluorescence of the donor bead in the fluorogenic substrate upon cleaving under proteolysis by the 3CLpro [24]. The fluorescence will be reduced by the presence of an inhibitor, describing the inhibitory activity of such an inhibitor toward the protease. Biological activity verification showed that this compound demonstrated enzymatic inhibition by $75 \%(500 \mu \mathrm{M})$ against the SARS-CoV-2 3CLpro enzyme. Although it is still less potent than the positive control $(\mathrm{GC} 376,77 \%$ at $100 \mu \mathrm{M})$, there is still a hope to proceed a series of 
concentration of compound 6 to calculate its real $\mathrm{IC}_{50}$. Unfortunately, due to our resource limitations, we have not performed this experiment yet.
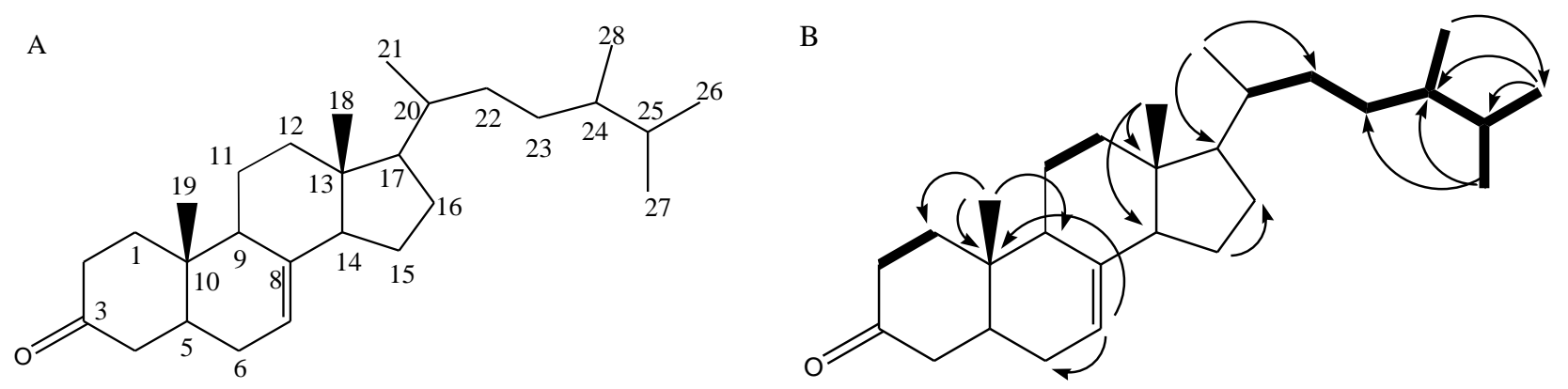

Figure 3. Molecular structure of 24-methylcholesta-7-en-3 $\beta$-on (A) and its H-H COSY and HMBC correlation (B).

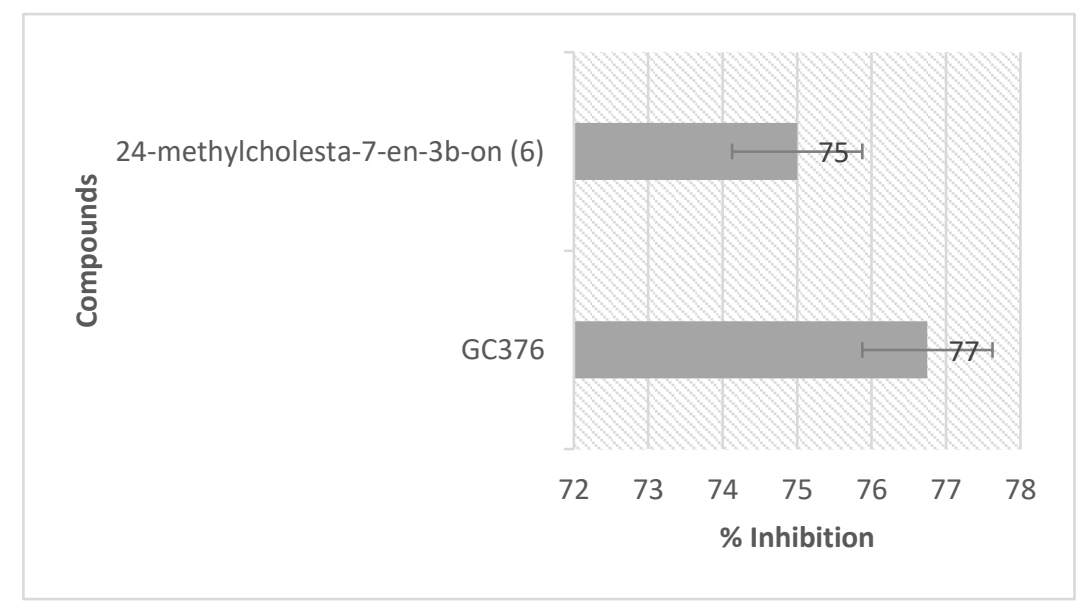

Figure 4. The \% inhibition of 24-methylcholesta-7-en-3 $\beta$-on (6) $(200 \mu \mathrm{g} / \mathrm{mL} \sim 500 \mu \mathrm{M})$ against SARSCoV-2 3CLpro by in vitro assay. GC376 $(100 \mu \mathrm{M})$ was used as the positive control and the experiment was triplicated.

\subsection{Molecular Dynamics (MD) Simulation}

MD simulations were performed to further analyze the complex stability of steroid compound $\mathbf{6}$ with the viral protease active site. The result can be seen in Figure 5. 6 was found to be relatively stable during $100 \mathrm{~ns}$ of the simulation times by distinction of RMSD complex ligand-protein and $\mathrm{C} \alpha$ protein below $3 \AA$.

Figure $6 \mathrm{~A}$ shows the residue interactions of viral protease with the steroid compound 6 . It shows that H-bond between carboxyl group of $\mathbf{6}$ and Cys44 was retained during the simulation time of $100 \mathrm{~ns}$. Meanwhile, hydrophobic interaction keep occurs with Met49, Met165, Leu167, Pro168, and Ala191. Figure 6B shows how 6 interacted mostly through H-bonds with Tyr54 and Cys44. Furthermore, Root Mean Square Fluctuation (RMSF) was used to evaluate the stability of the ligand with the specific amino acid residues of the SARS-CoV-2 3CLpro catalytic site, which are His41 and Cys145 [23]. Figure 6C shows that 6 might bind to catalytic sites both His41 and Cys145 with RMSF $0.755 \AA$ and $0.880 \AA$, respectively. The lowest RMSF with the specific amino acid residues could reflect the most stable interaction leading to the marker of such amino acids in the 3CLpro catalytic site. 


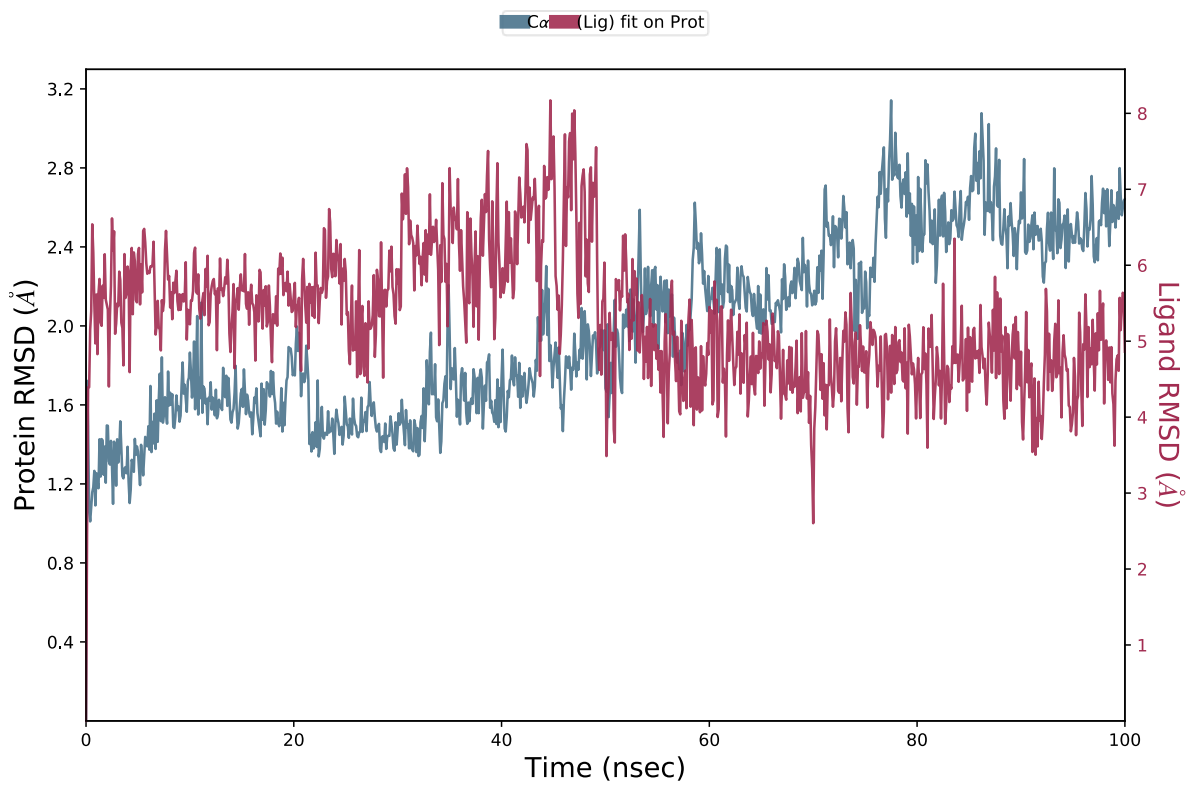

Figure 5. RMSD analysis of MD simulation trajectory (blue $=$ RMSD of the $C \alpha$ protein; red $=$ RMSD of the ligand-bound protein). The RMSD plot obtained for 6 on SARS-CoV-2 3CL protease complex (PDB ID 6m2n).

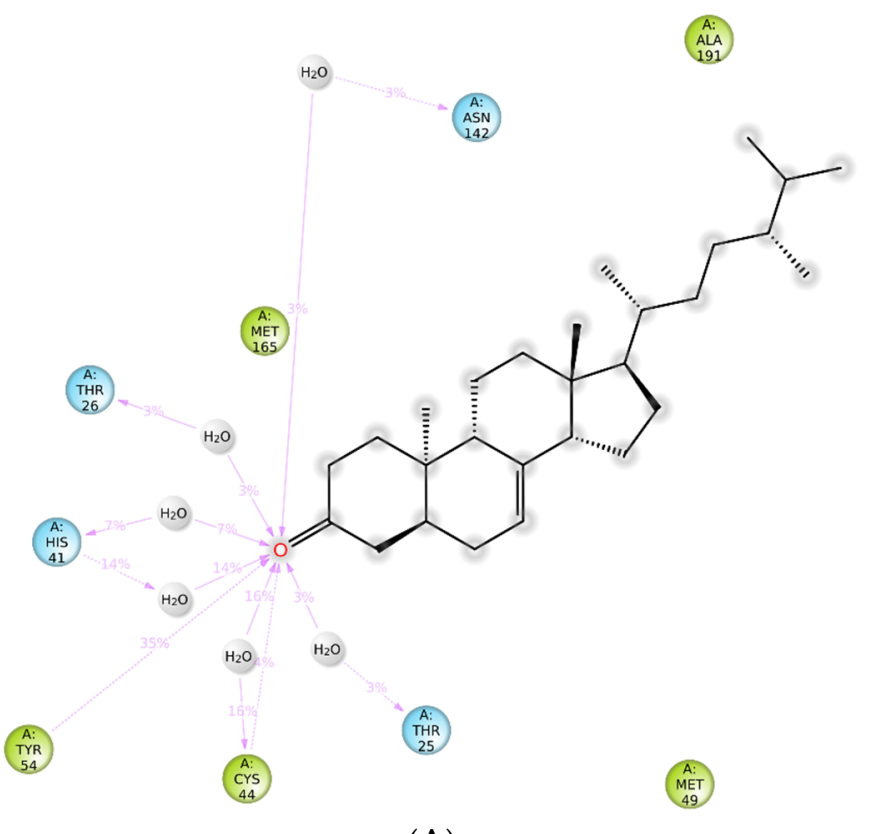

(A)

Figure 6. Cont. 


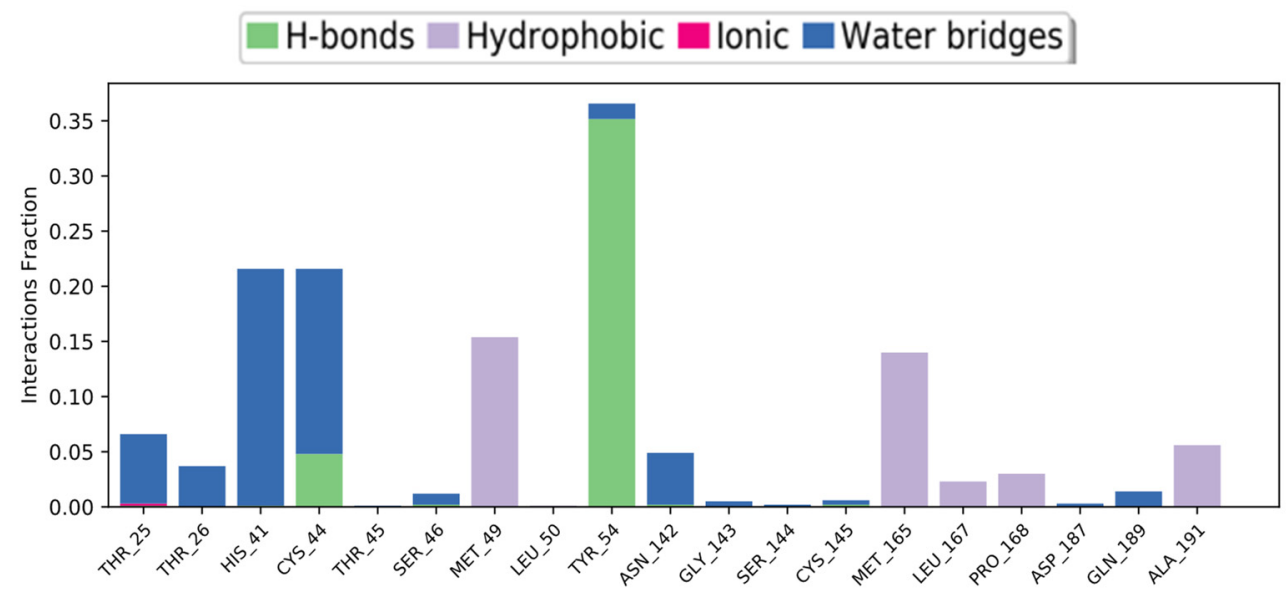

(B)

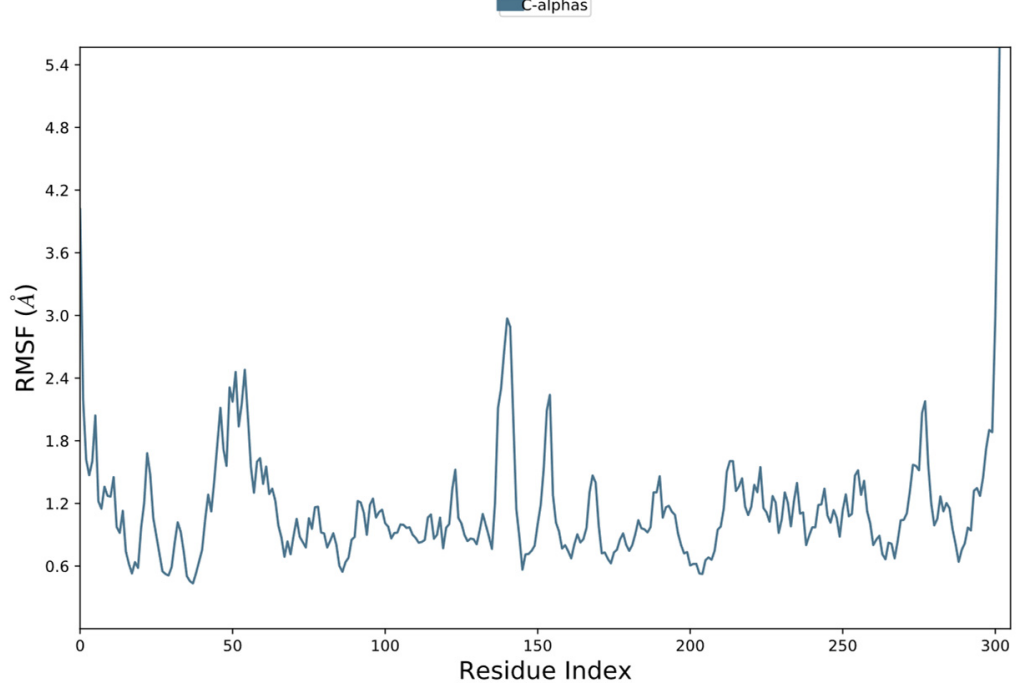

(C)

Figure 6. Molecular interaction (A), bonding type (B), and RMSF plot (C) of compound 6 with SARS-CoV-2 3CL protease after $100 \mathrm{~ns}$ MD simulation.

\section{Discussion}

Many bioactive compounds from ginger has been identified so far, mostly constituted by phenolics and terpenoids compounds [25]. The GC-MS analysis of methanol extract of Z. officinale identified terpenoids as major compounds in the pseudostems and rhizomes parts. Meanwhile, in leaves, the terpenoids were found as the second after fatty acids. Among the terpenoids, zerumbone was detected with the high percentage of $36.04 \%$, $15.25 \%$, and $2.25 \%$ on rhizomes, pseudostems, and leaves, respectively. Terpenoids, including steroids, were reported to possess potential antiviral activities, such as anti-hepatitis B, anti-HIV-1, hepatitis C, and anti-Herpes simplex virus [26-28]. Several studies also suggest the potency of terpenoids/steroids as SARS-CoV-2 3CL protease inhibitors [29-33]. Based on both chromatographic and spectroscopic data, the isolated compounds from our study were confirmed having terpenoids/steroids structure, such as $\mathbf{2}$ and $\mathbf{6}$.

The prediction for anti-SARS-CoV-2 on the identified compounds was performed by in silico methods employing docking molecular as a fast and less time-consuming strategy in the drug discovery process. Interestingly, steroid compounds 6, 7, and 8 were found to be more potential in inhibiting SARS-CoV-2 3CL protease enzymes than others. To date, there is no report for the presence of the steroid compound 6, 7, and 8 on Z. officinale extract. Compound $\mathbf{6}$ was reported as main sterol of Polyporus sulfureus. Meanwhile, compound 7 and $\mathbf{8}$ were reported from Samanea saman [34,35]. For biological activity, only compound $\mathbf{8}$ 
was reported to possess an antiproliferative effect on HeLa and RAW 264.7 cervical cancer cell lines [36]. The ability of steroids to inhibit the protease SARS-CoV-2 enzyme was also reported by Narkedhe et al. (2020), in which $\beta$-sitosterol, a common steroid from plant, was proposed by computational docking as inhibitor for main protease SARS-CoV-2. However, in vitro examination on SARS-Coronavirus 3CLpro showed weak inhibition with the $\mathrm{IC}_{50}$ of $1210 \mu \mathrm{M}[32,37]$. Further purification and characterization of the isolated compound by utilizing NMR analysis was successful in elucidating the chemical structure of $\mathbf{6}$. Biological activity verification showed that this compound demonstrated enzymatic inhibition by $75 \%$ against the SARS-CoV-2 3CLpro enzyme, slightly less than the positive control (GC376). Molecular dynamics simulation during 100 ns showed that 6 was more stable in complex with the viral protease. Its H-bond interactions mediated by water molecule with the His41 and Cys145 were retained during the $100 \mathrm{~ns}$ simulation which are in line with the reference ligand. This enzymatic inhibition supported the insight on molecular mechanism predicted by molecular docking and molecular dynamics simulations results suggesting that this approach can be used for discovering potential drug compounds from nature. The inhibitory potency of other isolates and the extract must be further tested and continued by in vivo and clinical studies to support the application as medicine for COVID-19 disease.

\section{Materials and Methods}

\subsection{General}

TLC aluminium sheets $20 \times 20 \mathrm{~cm}$ silica gel 60 F254, silica gel 60 (Merck, Darmstadt, Germany), and pre-coated TLC glass plates SIL G-25 UV254, $0.25 \mathrm{~mm}$ silica gel (Sigma, St. Louis, MO, USA) were used for thin layer chromatography analysis, vacuum liquid column chromatography, and preparative TLC, respectively. Spots on TLC were visualized by using spraying reagent of Liebermann Burchard for terpenoid/steroid detection. Shimadzu QP-2010 Gas Chromatograph Mass Spectrometer Ultra (Shimadzu, Kyoto, Japan) was used for GC-MS analysis. Acquity UPLC I-Class System with the XEVO G2-XS QTof Mass Spectrometer (Waters, Milford, MA, USA) was used for LC-MS/MS analysis, and NMR JEOL ECZ-500 and Variant Unity INOVA-500 Spectrometer (Agilent Technologies, Santa Carla, CA, USA) were used to elucidate the structural compounds. The nuclear magnetic resonance (NMR) was recorded at $500 \mathrm{MHz}$ for ${ }^{1} \mathrm{H}$ and $150 \mathrm{MHz}$ for ${ }^{13} \mathrm{C}$. Chemical shifts are given in $\delta(\mathrm{ppm})$ relative to TMS as internal standard, and deuterated chloroform was used as the solvent. The SARS-CoV-2 3CLpro \#78042 assay kit was purchased from BPS Bioscience Inc., (San Diego, CA, USA).

\subsection{Plant Material}

The Z. officinale plant was collected from Banggai Regency, Central Sulawesi, Indonesia, in December 2019. The plant was identified in Sulawesi Biodiversity Unit-Tadulako University (Herbarium Celebense) with the voucher specimen number 118/UN.28.UPTSDHS/LK/2019 and deposited at the Herbarium.

\subsection{Extraction and Isolation}

The whole part of the plant (1290 $\mathrm{g}$ of leaves, $310 \mathrm{~g}$ of pseudostem, and $368 \mathrm{~g}$ of rhizomes) was extracted by maceration method using methanol (14 L) for 3-5 days. The collected filtrate was evaporated to obtain viscous methanolic extract ( $18.58 \mathrm{~g}$ for leaves, $27.52 \mathrm{~g}$ for pseudostem, and $72.9 \mathrm{~g}$ for rhizome). The methanolic extract of each part of the plant (10 g) was further separated by applying liquid-liquid extraction using $n$-hexane:water (1:1) and successively continued by using ethyl acetate:water (1:1) to separately collect the $n$ hexane, soluble, and insoluble ethyl acetate fractions. The $n$-hexane fraction (each $3 \mathrm{~g}$ ) was poured into a vacuum column chromatography system packed by silica gel (60-120 mesh). Gradient system of solvent, starting from $n$-hexane 100\%, n-hexane/dichloromethane mixture, dichloromethane/ethyl acetate mixture and ended by ethyl acetate $100 \%$, ethyl acetate/methanol, and then methanol $100 \%$, was used to elute the crude fractions. A total of 78 fractions for leaf, 153 fractions for pseudostem, and 105 fractions for rhizome were 
collected. TLC analysis was used to identify the similar fractions, affording 21 fractions for leaf, 17 fractions for pseudostem, and 18 fractions for rhizome. The fraction 14 (leaves, $260 \mathrm{mg}$ ), 7 (pseudostems, $230 \mathrm{mg}$ ), and 46 (rhizomes, $320 \mathrm{mg}$ ), which was found to contain terpenoid/steroids, further isolated using preparative TLC with $n$-hexane:ethyl acetate (1:9) as a mobile phase. Isolation of fraction 14 (leaves) generated chromatogram where the third band with $R_{\mathrm{f}} 0.46$ (brown color with sulfuric acid-methanol) was taken to give the first isolate as colorless powder $(10.5 \mathrm{mg})$. Likewise, isolation of fraction 7 (pseudostem) shows $\mathrm{R}_{\mathrm{f}} 0.50$ (brown color with sulfuric acid-methanol) was taken to give the second isolate as colorless powder $(15.2 \mathrm{mg})$. Finally, isolation of fraction 46 (rhizome) demonstrates the first band with $R_{\mathrm{f}} 0.46$ (brown color with sulfuric acid-methanol) was taken to give the third isolate as colorless powder $(12.4 \mathrm{mg})$, as well. All isolated compounds were further analyzed by using LC-MS/MS. The isolated compound from fraction 7 (pseudostem) was further purified by successive preparative TLC using n-hexane:chloroform (5:2) as the mobile phase. The single spot at TLC $\left(\mathrm{R}_{\mathrm{f}} 0.71\right)$ was collected to give compound 6 ( $3.99 \mathrm{mg}$; yield $1.73 \%$ ).

\subsection{GC-MS Analysis}

Methanol extract of leaves, pseudostems, and rhizomes of $Z$. officinale were analyzed by GC-MS (Shimadzu QP-2010 Gas Chromatograph Mass Spectrometer Ultra), equipped by an autosampler AOC-20i and capillary column (SH-Rxi-5Sil MS) with the diameter $30 \mathrm{~m} \times 0.25 \mathrm{~mm} \times 0.25 \mu \mathrm{m}$. Helium was used as carrier gas $(1.0 \mathrm{~mL} / \mathrm{min})$, with temperature injection of $250{ }^{\circ} \mathrm{C}$; splitless mode; a column oven temperature of $70{ }^{\circ} \mathrm{C}$ at the beginning and held for $2 \mathrm{~min}$, and then ramped to $200^{\circ} \mathrm{C}$ at the rate of $10^{\circ} \mathrm{C} / \mathrm{min}$ and end temperature $280^{\circ} \mathrm{C}$ and held for $9 \mathrm{~min}$ at the rate $5^{\circ} \mathrm{C} / \mathrm{min}$; an MS ion source temperature of $200{ }^{\circ} \mathrm{C}$, and an interface temperature of $280{ }^{\circ} \mathrm{C}$, were set. The secondary metabolites were identified by comparing the experimental molecular mass spectra and base peak of each chromatogram with the Wiley and NIST database libraries.

\subsection{LC-MS/MS Analysis}

Each of the isolated compounds $(1 \mathrm{mg})$ was dissolved in $1 \mathrm{~mL}$ of methanol (LC-MS chromasolv ${ }^{\circledR}$ grade). One microliter aliquot of the sample was injected into the column. Formic acid $0.1 \%(v / v)$ in water and acetonitrile plus formic acid $0.1 \%(v / v)$ were used as gradient solvent for eluting the sample that initially started by ratio $95: 5$, continued by ratio $60: 40$ from 1.00 to $8.00 \mathrm{~min}$, ratio $0: 100$ from 8.00 to $13.00 \mathrm{~min}$, and at the end with the ratio 95:5. The flowing rate is $0.3 \mathrm{~mL} / \mathrm{min}$. The instrument was set as follows: acquisition time $0.00-16.00 \mathrm{~min}$, start mass $50.00-1200.00 \mathrm{~m} / \mathrm{z}$, scan time $0.100 \mathrm{~s}$, low CE $6 \mathrm{eV}$, high CE 10-40 eV, cone voltage $30 \mathrm{~V}$, collision energy $6 \mathrm{eV}$; acquisition mode ESI (+), capillary voltage $2 \mathrm{kV}$, source temperature $120^{\circ} \mathrm{C}$, desolvation temperature $500^{\circ} \mathrm{C}$, cone gas flow $50 \mathrm{~L} / \mathrm{h}$, and desolvation gas flow $1000 \mathrm{~L} / \mathrm{h}$, sample temperature $20^{\circ} \mathrm{C}$, and column temperature $40^{\circ} \mathrm{C}$. The data obtained were processed by using UNIFI software (version 1.8, Waters Corporation, Milford, MA, USA) with a screening solution workflow, which helped in automated data processing for reporting the positive identifications. The result was compared with database that collected more than 1200 compounds based on chemical structure, molecular formula, and molecular mass from various web-based resources.

\subsection{Molecular Docking}

For the molecular docking, the protein used was the crystal structures of SARS-CoV-2 $3 \mathrm{CL}$ protease with the pdb code $6 \mathrm{~m} 2 \mathrm{n}$ [23]. The protein was optimized by Protein Preparation Wizard module in Maestro Schrödinger 2020-3 software (Schrödinger, New York, NY, USA) $[38,39]$. The missing hydrogens were added during optimization process, and partial charges were also assigned using OPLS_2005 forcefield. Moreover, hydrogens and heavy atoms in protein were prepared in restrained minimization state. The $2 \mathrm{D}$ structures of Z. officinale compounds identified from LC-MS/MS analysis were converted to 3D structures using Maestro Schrödinger 2020-3 by LigPrep Module and OPLS_2005 forcefield 
with $\mathrm{pH}$ adjusted 7.4 via Epik [40]. LigPrep facilitated the protonation, tautomeric, and ionization states of each compound, as well as correct proper bond orders. In order to specify the docking region, the grid box was distinguished by selecting co-crystallized ligand of protease receptor to maintain that the center of docked compounds is in a similar dimension with the binding box. Docking protocol was run in extra precision (XP) mode through Glide using OPLS_2005 forcefield with flexible ligand and rigid receptor conditions [41,42]. To evaluate the potential of each ligand as 3CL protease inhibitor of SARS-CoV-2, molecular mechanics-generalized Born surface area (MM-GBSA) was used for scoring the docked pose of the ligand $[21,43,44]$.

\subsection{SARS-CoV-2 3CL Protease In Vitro Inhibition Assay}

The assay buffer was prepared by adding $12 \mu \mathrm{L} 0.5 \mathrm{M}$ DTT for a total of $6 \mathrm{~mL}$ of assay buffer, which then would be furtherly used. The enzyme and the substrate were each diluted separately by adding, respectively, $3.95 \mathrm{~mL}$ and $950 \mu \mathrm{L}$ of the previously prepared assay buffer (with DTT). The sample for the assay was prepared by dissolving it in DMSO at 100-fold concentration than the final or required concentration in a 96-well microplate. The final concentration of the sample was $200 \mu \mathrm{g} / \mathrm{mL} 500 \mu \mathrm{M}$. Inhibitor control used in this assay was a peptidomimetic called GC376 diluted in $200 \mu \mathrm{L}$ water for $500 \mu \mathrm{M}$ solution. The assay was carried by adding them in the following order: $30 \mu \mathrm{L}$ of enzyme $(5 \mathrm{ng} / \mu \mathrm{L})$, required volume of sample or inhibitor (GC376), and assay buffer (with DTT) (if necessary) to a total volume of $40 \mu \mathrm{L}$. The initial mixture was incubated for $30 \mathrm{~min}$ at $25^{\circ} \mathrm{C}$ with slow shaking, and then followed by the addition of $10 \mu \mathrm{L}$ of substrate $(250 \mu \mathrm{M})$ for a mixture with the final volume of $50 \mu \mathrm{L}$. The mixtures were then incubated overnight and measured with Synergy HTX-3 Multi-mode Reader (Winooski, VT, USA) at 360/460 nm.

\subsection{Molecular Dynamics Simulation}

A molecular dynamics (MD) study was conducted using the Desmond module in Schrödinger software (Version) [45-47]. Before commencing the MD process, the system was constructed by selecting ligand-protein complexes and submerged them into an SPC (simple point charge) water box at $10 \AA$. Moreover, to the system was added Counter ions (33 $\mathrm{Na}^{+}$, and $29 \mathrm{Cl}^{-}$ions), to neutralize charges; additionally, Salts ions (sodium and chloride) were also set to $0.15 \mathrm{M}$ to approximate physiological conditions. The MD simulation was conducted in NPT conditions (temperature $300 \mathrm{~K}$ and pressure $1.63 \mathrm{bar}$ ) for $50 \mathrm{~ns}$ with recording intervals set to $1.2 \mathrm{ps}$ for energy and $20 \mathrm{ps}$ for trajectory. Afterward, the MD simulations were run with the OPLS_2005 forcefield.

\section{Conclusions}

GC-MS, LC-MS/MS analysis, and docking molecular simulations were successfully used to identify the potential compounds from Zingiber officinale plant with the activity as inhibitor for SARS-CoV-2 3CL protease enzyme. Compound 6, 7, and 8 were steroid class compounds, found in pseudostem part, that showed low values of predictive binding energy (MMGBSA). Further purification and NMR characterization led to the structure of 6 that showed inhibitory activity 75\%, slightly less than the positive control GC376 (77\%). Further molecular dynamics simulation showed that $\mathbf{6}$ was found to be more stable during 100 ns molecular dynamics simulation.

Supplementary Materials: The following are available online. Table S1. GC-MS analysis of leaves, pseudostems and rhizomes of Z. officinale methanol extract, Figure S1. The GC-MS spectral data of Z. officinale leaves (A). pseudostems (B) and rhizomes (C) of methanol extract, Figure S2: The TLC chromatogram of fraction number 14, 7, and 46 of Z. officinale leaves (A). pseudostems (B) and rhizomes (C) of $n$-hexane extract. The spots were detected under UV light $254 \mathrm{~nm}$ (left), and after spraying with Liebermann-Burchard reagent (right). The isolated spots were circled out upon the chromatograms, Figure S3: LC-MS/MS spectral data of compounds isolated from leaves of Z. offiicinale n-hexane extract. A. (E)-Hexadecyl-ferulate, B. Isocyperol, C. N-Isobutyl$(2 E, 4 E)$-octadecadienamide, D. Nootkatone, E. Candidate mass $\mathrm{C}_{22} \mathrm{H}_{45} \mathrm{NO}$, Figure S4: LC-MS/MS 
spectral data of compounds isolated from pseudostem of Z. offiicinale n-hexane extract. A. Spinasterone, B. Spinasterol, C. 24-methylcholesta-7-en-3 $\beta$-on, Figure S5: LC-MS/MS spectral data of compounds isolated from rhizome of Z. offiicinale n-hexane extract. A. (E)-Hexadecyl-ferulate, B. 5-hydro-7,8,2' -trimethoxyflavanone C. Isocyperol, D. N-Isobutyl-(2E,4E)-octadecadienamide, E. Nootkatone, Figure S6: ${ }^{1} \mathrm{H}-\mathrm{NMR}$ spectral data of 24 -methylcholesta-7-en-3 $\beta$-on, Figure S7: ${ }^{13} \mathrm{C}-\mathrm{NMR}$ data of 24-methylcholesta-7-en-3 $\beta$-on, Figure S8: DEPT spectral data of 24-methylcholesta-7-en-3 $\beta$-on, Figure S9: HSQC spectral data of 24-methylcholesta-7-en-3 $\beta$-on, Figure S10: H-H COSY spectral data of 24-methylcholesta-7-en-3 $\beta$-on. Figure S11: HMBC spectral data of 24-methylcholesta-7-en-3 $\beta$-on.

Author Contributions: M.S.Z., R.P. and A.W. conceived and designed the study; S.M., A.W. and M.H. performed the experiments; S.M. software; M.S.Z., S.M., M.H. and M.A. analyzed the data; M.S.Z., R.P. and M.H., wrote the paper. All authors have read and agreed to the published version of the manuscript.

Funding: This research was funded by the Directorate General of Higher Education, The Ministry of Education, Culture, Research and Technology, Republic of Indonesia, through Basic Research Grant with the contract number 919a/UN28.2/PL/2021.

Institutional Review Board Statement: “Not applicable." for studies not involving humans or animals. Informed Consent Statement: “Not applicable." for studies not involving humans.

Data Availability Statement: Data is contained within the article or supplementary material.

Acknowledgments: Authors acknowledge the Directorate General of Higher Education, The Ministry of Education, Culture, Research and Technology, Republic of Indonesia, for financial supporting of this research. Authors also acknowledge The Indonesian Institute of Science (LIPI) for helping in spectroscopic analysis. Linda, Zulfatul Lailiyah, and Satrima Widya were also acknowledged for their assistance during this research.

Conflicts of Interest: The authors declare no conflict of interest.

\section{References}

1. Zheng, J. SARS-CoV-2: An Emerging Coronavirus that Causes a Global Threat. Int. J. Biol. Sci. 2020, 16, 1678-1685. [CrossRef]

2. De Almeida, S.M.V.; Santos Soares, J.C.; Dos Santos, K.L.; Alves, J.E.F.; Ribeiro, A.G.; Jacob, İ.T.T.; da Silva Ferreira, C.J.; Dos Santos, J.C.; de Oliveira, J.F.; de Carvalho Junior, L.B.; et al. COVID-19 therapy: What weapons do we bring into battle? Bioorg. Med. Chem. 2020, 28, 115757. [CrossRef] [PubMed]

3. Farooq, S.; Ngaini, Z. Natural and Synthetic Drugs as Potential Treatment for Coronavirus Disease 2019 (COVID-2019). Chem. Afr. 2020, 4, 1-13. [CrossRef]

4. Wu, C.; Liu, Y.; Yang, Y.; Zhang, P.; Zhong, W.; Wang, Y.; Wang, Q.; Xu, Y.; Li, M.; Li, X.; et al. Analysis of therapeutic targets for SARS-CoV-2 and discovery of potential drugs by computational methods. Acta Pharm. Sin. B 2020, 10, 766-788. [CrossRef]

5. Dias, D.A.; Urban, S.; Roessner, U. A Historical Overview of Natural Products in Drug Discovery. Metabolites 2012, 2, 303-336. [CrossRef]

6. Cragg, G.M.; Newman, D.J. Natural products: A continuing source of novel drug leads. Biochim. Biophys. Acta (BBA)-Gen. Subj. 2013, 1830, 3670-3695. [CrossRef] [PubMed]

7. Vijendra Kumar, N.; Murthy, P.S.; Manjunatha, J.R.; Bettadaiah, B.K. Synthesis and quorum sensing inhibitory activity of key phenolic compounds of ginger and their derivatives. Food Chem. 2014, 159, 451-457. [CrossRef]

8. Nile, S.; Park, S.W. Chromatographic analysis, antioxidant, anti-inflammatory, and xanthine oxidase inhibitory activities of ginger extracts and its reference compounds. Ind. Crops Prod. 2015, 70, 238-244. [CrossRef]

9. Citronberg, J.; Bostick, R.; Ahearn, T.; Turgeon, D.K.; Ruffin, M.; Djuric, Z.; Sen, A.; Brenner, D.E.; Zick, S.M. Effects of Ginger Supplementation on Cell-Cycle Biomarkers in the Normal-Appearing Colonic Mucosa of Patients at Increased Risk for Colorectal Cancer: Results from a Pilot, Randomized, and Controlled Trial. Cancer Prev. Res. 2013, 6, 271-281. [CrossRef]

10. Zhang, M.; Viennois, E.; Prasad, M.; Zhang, Y.; Wang, L.; Zhang, Z.; Han, M.K.; Xiao, B.; Xu, C.; Srinivasan, S.; et al. Edible ginger-derived nanoparticles: A novel therapeutic approach for the prevention and treatment of inflammatory bowel disease and colitis-associated cancer. Biomaterials 2016, 101, 321-340. [CrossRef]

11. Townsend, E.A.; Siviski, M.E.; Zhang, Y.; Xu, C.; Hoonjan, B.; Emala, C.W. Effects of Ginger and Its Constituents on Airway Smooth Muscle Relaxation and Calcium Regulation. Am. J. Respir. Cell Mol. Biol. 2013, 48, 157-163. [CrossRef]

12. Wei, C.-K.; Tsai, Y.-H.; Korinek, M.; Hung, P.-H.; El-Shazly, M.; Cheng, Y.-B.; Wu, Y.-C.; Hsieh, T.-J.; Chang, F.-R. 6-Paradol and 6-Shogaol, the Pungent Compounds of Ginger, Promote Glucose Utilization in Adipocytes and Myotubes, and 6-Paradol Reduces Blood Glucose in High-Fat Diet-Fed Mice. Int. J. Mol. Sci. 2017, 18, 168. [CrossRef] [PubMed] 
13. Suk, S.; Kwon, G.T.; Lee, E.; Jang, W.J.; Yang, H.; Kim, J.H.; Thimmegowda, N.R.; Chung, M.-Y.; Kwon, J.Y.; Yang, S.; et al. Gingerenone A, a polyphenol present in ginger, suppresses obesity and adipose tissue inflammation in high-fat diet-fed mice. Mol. Nutr. Food Res. 2017, 61, 1700139. [CrossRef]

14. Akinyemi, A.; Thome, G.R.; Morsch, V.M.; Stefanello, N.; Goularte, J.F.; Belló-Klein, A.; Oboh, G.; Schetinger, M.R.C. Effect of dietary supplementation of ginger and turmeric rhizomes on angiotensin-1 converting enzyme (ACE) and arginase activities in L-NAME induced hypertensive rats. J. Funct. Foods 2015, 17, 792-801. [CrossRef]

15. Ho, S.-C.; Chang, K.-S.; Lin, C.-C. Anti-neuroinflammatory capacity of fresh ginger is attributed mainly to 10-gingerol. Food Chem. 2013, 141, 3183-3191. [CrossRef] [PubMed]

16. Rasool, A.; Khan, M.-U.; Ali, M.A.; Anjum, A.A.; Ahmed, I.; Aslam, A.; Mustafa, G.; Masood, S.; Ali, M.A.; Nawaz, M. Anti-avian influenza virus H9N2 activity of aqueous extracts of Zingiber officinalis (Ginger) and Allium sativum (Garlic) in chick embryos. Pak. J. Pharm. Sci. 2017, 30, 1341-1344.

17. Chang, J.-S.; Wang, K.C.; Yeh, C.F.; Shieh, D.E.; Chiang, L.C. Fresh ginger (Zingiber officinale) has anti-viral activity against human respiratory syncytial virus in human respiratory tract cell lines. J. Ethnopharmacol. 2012, 145, 146-151. [CrossRef] [PubMed]

18. Ahkam, A.H.; Hermanto, F.E.; Alamsyah, A.; Aliyyah, I.H.; Fatchiyah, F. Virtual prediction of antiviral potential of ginger (Zingiber officinale) bioactive compounds against spike and MPro of SARS-CoV2 protein. Berk. Penelit. Hayati 2020, $25,52-57$. [CrossRef]

19. Pan, M.; Lei, Q.; Zang, N.; Zhang, H. A Strategy Based on GC-MS/MS, UPLC-MS/MS and Virtual Molecular Docking for Analysis and Prediction of Bioactive Compounds in Eucalyptus Globulus Leaves. Int. J. Mol. Sci. 2019, 20, 3875. [CrossRef]

20. De Oliveira, M.S.; da Silva, V.M.P.; Freitas, L.C.; Silva, S.G.; Cruz, J.N.; Andrade, E.H.D.A. Extraction Yield, Chemical Composition, Preliminary Toxicity of Bignonia nocturna (Bignoniaceae) Essential Oil and in Silico Evaluation of the Interaction. Chem. Biodivers. 2021, 18, e2000982. [CrossRef]

21. Santana de Oliveira, M.; da Cruz, J.N.; Almeida da Costa, W.; Silva, S.G.; Brito, M.D.P.; de Menezes, S.A.F.; de Jesus Chaves Neto, A.M.; de Aguiar Andrade, E.H.; de Carvalho Junior, R.N. Chemical Composition, Antimicrobial Properties of Siparuna guianensis Essential Oil and a Molecular Docking and Dynamics Molecular Study of its Major Chemical Constituent. Molecules 2020, 25, 3852. [CrossRef]

22. Hartini, Y.; Saputra, B.; Wahono, B.; Auw, Z.; Indayani, F.; Adelya, L.; Namba, G.; Hariono, M. Biflavonoid as potential 3-chymotrypsin-like protease (3CLpro) inhibitor of SARS-Coronavirus. Results Chem. 2020, 3, 100087. [CrossRef] [PubMed]

23. Su, H.X.; Yao, S.; Zhao, W.F.; Li, M.J.; Liu, J.; Shang, W.J.; Xie, H.; Ke, C.Q.; Hu, H.C.; Gao, M.N.; et al. Anti-SARS-CoV-2 activities in vitro of Shuanghuanglian preparations and bioactive ingredients. Acta Pharmacol. Sin. 2020, 41, 1167-1177. [CrossRef] [PubMed]

24. Ong, I.L.H.; Yang, K.-L. Recent developments in protease activity assays and sensors. Analyst 2017, 142, 1867-1881. [CrossRef] [PubMed]

25. Mao, Q.-Q.; Xu, X.-Y.; Cao, S.-Y.; Gan, R.-Y.; Corke, H.; Beta, T.; Li, H.-B. Bioactive Compounds and Bioactivities of Ginger (Zingiber officinale Roscoe). Foods 2019, 8, 185. [CrossRef] [PubMed]

26. Denaro, M.; Smeriglio, A.; Barreca, D.; De Francesco, C.; Occhiuto, C.; Milano, G.; Trombetta, D. Antiviral activity of plants and their isolated bioactive compounds: An update. Phytother. Res. 2019, 34, 742-768. [CrossRef]

27. Musarra-Pizzo, M.; Pennisi, R.; Ben-Amor, I.; Mandalari, G.; Sciortino, M. Antiviral Activity Exerted by Natural Products against Human Viruses. Viruses 2021, 13, 828. [CrossRef]

28. Xiao, S.; Tian, Z.; Wang, Y.; Si, L.; Zhang, L.; Zhou, D. Recent progress in the antiviral activity and mechanism study of pentacyclic triterpenoids and their derivatives. Med. Res. Rev. 2018, 38, 951-976. [CrossRef] [PubMed]

29. Diniz, L.R.L.; Perez-Castillo, Y.; Elshabrawy, H.A.; Filho, C.; da, S.M.B.; de Sousa, D.P. Bioactive Terpenes and Their Derivatives as Potential SARS-CoV-2 Proteases Inhibitors from Molecular Modeling Studies. Biomolecules 2021, 11, 74. [CrossRef]

30. Gyebi, G.A.; Ogunro, O.B.; Adegunloye, A.P.; Ogunyemi, O.M.; Afolabi, S.O. Potential inhibitors of coronavirus 3-chymotrypsinlike protease (3CL pro): An in silico screening of alkaloids and terpenoids from African medicinal plants. J. Biomol. Struct. Dyn. 2021, 39, 3396-3408. [PubMed]

31. Loschwitz, J.; Jäckering, A.; Keutmann, M.; Olagunju, M.; Eberle, R.J.; Coronado, M.A.; Olubiyi, O.O.; Strodel, B. Novel inhibitors of the main protease enzyme of SARS-CoV-2 identified via molecular dynamics simulation-guided in vitro assay. Bioorg. Chem. 2021, 111, 104862. [CrossRef] [PubMed]

32. Lin, C.-W.; Tsai, F.-J.; Tsai, C.-H.; Lai, C.-C.; Wan, L.; Ho, T.-Y.; Hsieh, C.-C.; Chao, P.-D.L. Anti-SARS coronavirus 3C-like protease effects of Isatis indigotica root and plant-derived phenolic compounds. Antivir. Res. 2005, 68, 36-42. [CrossRef]

33. Olubiyi, O.O.; Olagunju, M.; Keutmann, M.; Loschwitz, J.; Strodel, B. High Throughput Virtual Screening to Discover Inhibitors of the Main Protease of the Coronavirus SARS-CoV-2. Molecules 2020, 25, 3193. [CrossRef]

34. Kac, D.; Barbieri, G.; Falco, M.; Seldes, A.; Gros, E. The major sterols from three species of polyporaceae. Phytochemistry 1984, 23, 2686-2687. [CrossRef]

35. Y Ragasa, C.; F Galian, R.; Arenal, M.; Tan, V.; Shen, C. Triterpenes and Sterols from Samanea saman. Res. J. Pharm. Biol. Chem. Sci. 2014, 5, 1501-1507.

36. Meneses-Sagrero, S.E.; Navarro-Navarro, M.; Ruiz-Bustos, E.; Del-Toro-Sánchez, C.L.; Jiménez-Estrada, M.; Robles-Zepeda, R.E. Antiproliferative activity of spinasterol isolated of Stegnosperma halimifolium (Benth, 1844). Saudi Pharm. J. 2017, 25, 1137-1143. [CrossRef] [PubMed] 
37. Narkhede, R.R.; Pise, A.V.; Cheke, R.S.; Shinde, S.D. Recognition of Natural Products as Potential Inhibitors of COVID-19 Main Protease (Mpro): In-Silico Evidences. Nat. Prod. Bioprospect. 2020, 10, 297-306. [CrossRef]

38. Schrödinger Release 2020-3: Protein Preparation Wizard; Schrödinger, LLC: New York, NY, USA, 2020.

39. Sastry, G.M.; Adzhigirey, M.; Day, T.; Annabhimoju, R.; Sherman, W. Protein and ligand preparation: Parameters, protocols, and influence on virtual screening enrichments. J. Comput. Mol. Des. 2013, 27, 221-234. [CrossRef]

40. Schrödinger Release 2020-3: Epik; Schrödinger, LLC: New York, NY, USA, 2020.

41. Schrödinger Release 2020-3: Glide; Schrödinger, LLC: New York, NY, USA, 2020.

42. Friesner, R.A.; Murphy, R.B.; Repasky, M.P.; Frye, L.L.; Greenwood, J.R.; Halgren, T.A.; Sanschagrin, P.C.; Mainz, D.T. Extra Precision Glide: Docking and Scoring Incorporating a Model of Hydrophobic Enclosure for Protein-Ligand Complexes. J. Med. Chem. 2006, 49, 6177-6196. [CrossRef]

43. Schrödinger Release 2020-3: Prime; Schrödinger, LLC: New York, NY, USA, 2020.

44. Genheden, S.; Ryde, U. The MM/PBSA and MM/GBSA methods to estimate ligand-binding affinities. Expert Opin. Drug Discov. 2015, 10, 449-461. [CrossRef]

45. Schrödinger Release 2020-1: Desmond Molecular Dynamics System; D.E. Shaw Research: New York, NY, USA, 2020.

46. Schrödinger Release 2020-1: Maestro Desmond Interoperability Tools; Schrödinger: New York, NY, USA, 2020.

47. Bowers, K.J.; Chow, D.E.; Xu, H.; Dror, R.O.; Eastwood, M.P.; Gregersen, B.A.; Klepeis, J.L.; Kolossvary, I.; Moraes, M.A.; Sacerdoti, F.D.; et al. Scalable Algorithms for Molecular Dynamics Simulations on Commodity Clusters. In Proceedings of the 2006 ACM/IEEE Conference on Supercomputing, Tampa, FL, USA, 11-17 November 2006; p. 43. [CrossRef] 